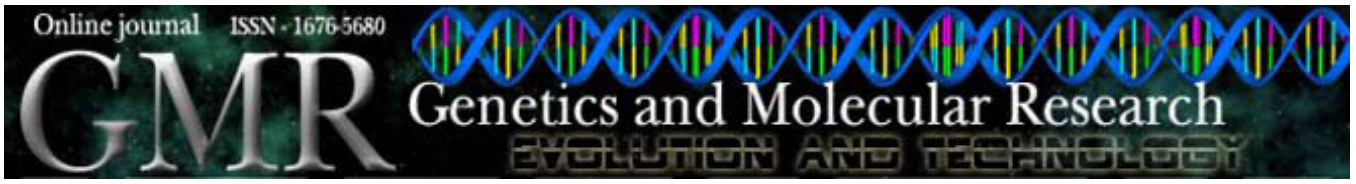

\title{
Drought tolerant stem anatomy characteristics in Manihot esculenta (Euphorbiaceae) and a wild relative
}

\author{
N.M.A. Nassar ${ }^{1}$, L.F.A. Abreu${ }^{1}$, D.A.P. Teodoro ${ }^{2}$ and D. Graciano-Ribeiro ${ }^{2}$ \\ ${ }^{1}$ Departamento de Genética e Morfologia, ${ }^{2}$ Departamento de Botânica, \\ Universidade de Brasília, Brasília, DF, Brasil \\ Corresponding author: D. Graciano-Ribeiro \\ E-mail: graciano@unb.br
}

Genet. Mol. Res. 9 (2): 1023-1031 (2010)

Received February 21, 2010

Accepted March 16, 2010

Published June 1, 2010

DOI 10.4238/vol9-2gmr800

\begin{abstract}
The stem structure of two cassava cultivars, UnB 99 and UnB 110, known for being adapted to humid conditions and tolerant to drought, respectively, and of a wild species, Manihot glaziovii, was examined anatomically. Free-hand sections of secondary stems were made, clarified with $50 \%$ sodium hypochlorite solution, stained with $1 \%$ alcian-blue safranin, and then passed through an ethanol series and butyl acetate, followed by mounting in synthetic resin. M. glaziovii stems had dense prismatic and druse crystals in the cortical parenchyma, along with abundant gelatinous fibers. The pericycle fibers also had thicker walls. An absence of crystals, offset by abundant starch, was observed in clone UnB 99. In M. glaziovii, abundant tyloses were found in vessel elements; these were rare in clones UnB 99 and UnB 110. The wild species had larger vascular vessels; the secondary xylem showed very little starch, unlike UnB 99 and UnB 110. In clone UnB 110, starch was observed in the cortical region, and medulla and gelatinous fibers were found in the pericycle and secondary xylem. Brown stem color was found to be associated with tolerance to drought.
\end{abstract}

Key words: Manihot glaziovii; Cassava cultivars; Stem anatomy; Prismatic and druse crystals; Drought resistance; Gelatinous fibers 


\section{INTRODUCTION}

Cassava is the most important food staple for poor people in the tropics and subtropics. Its production and growth are severely limited in certain semi-arid areas such as Northeastern Brazil and Northern Nigeria due to drought conditions.

Currently, drought is one of the factors that limits cassava production (Nassar, 2002; Nassar et al., 2008a,b).

This prompted us to look at our breeding program to identify morphological markers that may be used for selecting cultivars, which resist drought conditions (Nassar, 2002; Nassar, 2007; Nassar et al., 2008a). We also studied the anatomical structure of different types of cultivars and wild species known to have different reactions to drought (Nassar et al., 2008b; Graciano-Ribeiro, 2008; Graciano-Ribeiro et al., 2009a,b). These cultivars are: UnB 99, which is known for low tolerance to drought, and UnB 110, which is known for high tolerance.

In the 1980s, some researchers believed that the high frequency of stomata may be related indirectly to this character because they control water evaporation (De Tafur et al., 1997; El-Sharkawy, 2004). However, this idea was proven to be wrong. For a number of years, the referred authors selected low-frequency stomata plants, which were evaluated under dry conditions but no improvement to productivity or survival could be found.

Stomata frequency is probably related somehow to drought tolerance in certain groups such as Gramineae, but this is not the case in cassava. Other mechanisms were studied by other researchers such as cell size in drought tolerant plants (Levitt, 1972). A third approach taken by researchers in the study area was the number of leaves per plant. The process of stem growth is less studied, but is probably affected by the same forces that limit leaf growth during stress (Taiz and Zeiger, 1998).

The objectives of this study were to compare the anatomical structures existing in the stem of the UnB 110 genotype and Manihot glaziovii, considered to be resistant to drought, both presenting dark green to brown stems, with the stem of a genotype (UnB 99) variety that has low resistance to drought and light green bark, and to see if either of them can be an indicator of drought tolerance and shed light on the mechanism of drought tolerance in cassava.

\section{MATERIAL AND METHODS}

A wild Manihot species, named M. glaziovii Muell., and two clones, UnB 99 and UnB 110, were used in this experiment. The wild species is known for its tolerance to drought and is native to semi-arid parts of Brazil. Clone UnB 99 is known traditionally by the name Branca Santa Catarina. It grows well and is adapted to humid areas, particularly the Southeast of Brazil. Clone UnB 110 was developed by the senior author by selection from the progeny of an interspecific hybrid of M. glaziovii with cassava. They were grown at the biological station of the University of Brasília.

Mature stem samples were collected in the midline between the 3rd and 4th internodes from the apex. Three individuals were selected for each material. After collecting the material in the field, fragments were fixed in 70\% FAA (Johansen, 1940) for a period of $24 \mathrm{~h}$ and preserved in $70 \%$ ethanol and remained immersed in the liquid until the next steps of processing.

The transverse and longitudinal sections were performed free-hand on a microtome 
table (R. Jungag, Heidelberg), clarified with a solution of sodium hypochlorite, 20 and $50 \%$ (Kraus and Arduin, 1997), stained with 1\% safranin and 1\% aqueous alcian blue (Luque et al., 1996), dehydrated in ethanol series, cleared in butyl acetate and mounted in synthetic resin (Paiva et al., 2006).

The slides were analyzed with a light microscope and photomicrographs were obtained with the aid of an Olympus CX 31 microscope coupled to a digital camera.

\section{RESULTS}

In our study, we looked for possible anatomical differences in the three materials, and how closely they are associated with a morphological marker that could be used for selection of drought tolerant types. The three materials have significant differences with respect to tolerance to drought. While $M$. glaziovii grows in natural habitats with the lowest annual precipitation in Brazil, clone UnB 99 is known for being indigenous to one of the most humid regions in this country.

Transverse sections of the stems analyzed show the circular shape and secondary growth with vascular cambium and periderm. In the UnB 99 genotype there is remaining epidermis, in M. glaziovii there is a thicker phellem layer.

The cortical region (collenchyma and external and internal parenchyma layers) is thicker in M. glaziovii.

The starch sheath is one-layer of cells in all stems. Cell content frequency (starch grains, druse and prismatic crystals) is variable. The UnB 99 genotype has more starch grains and crystals (Figure 1A).

In relation to pericycle fibers, the UnB 110 genotype has more layers (1-5). The stems have different cell wall thicknesses, thin in the UnB 99 genotype and thick (with reduced lumen) in M. glaziovii (Figure 1A-C). In this region there are gelatinous fibers, which are abundant in the UnB 110 genotype (Figure 1B) and rare in M. glaziovii and the UnB 99 genotype (Figure 1A-C).

External primary phloem tissue is thicker in M. glaziovii (12-15 layers) and thinner in the UnB 110 genotype. However, UnB 110 and UnB 99 genotypes have higher cell content frequency in this tissue for starch grains, druse and prismatic-rhomboid crystals, in descending order.

Secondary phloem tissue has more layers in M. glaziovii (20-25). Parenchyma rays are continuous with those in the secondary xylem, but phloem rays are enlarged, and more conspicuous in M. glaziovii. In the UnB 99 genotype cell content, starch and druses are abundant. In all stems, laticifers are interleaved with sieve elements, companion and parenchyma cells.

Growth rings are easily visible in M. glaziovii and less distinct in the others (Figure 1D, E and F). M. glaziovii has more cell layers in xylem tissue; these cells are bigger and have thick walls (Figure 1F and Figure 2C and F). The secondary xylem tissue of all stems has starch grains in radial parenchyma cells and in fibers/fibrotracheids, especially in UnB 99 and UnB 110 genotypes (Figure 2B and D). Fibers (Figure 2A, B and C), which are thick and well lignified are abundant in xylem tissue. Together with these fibers there are gelatinous fibers in all stems, especially in M. glaziovii; gelatinous fibers form continuous layers in regions that correspond to early wood (Figure 2E and F). 

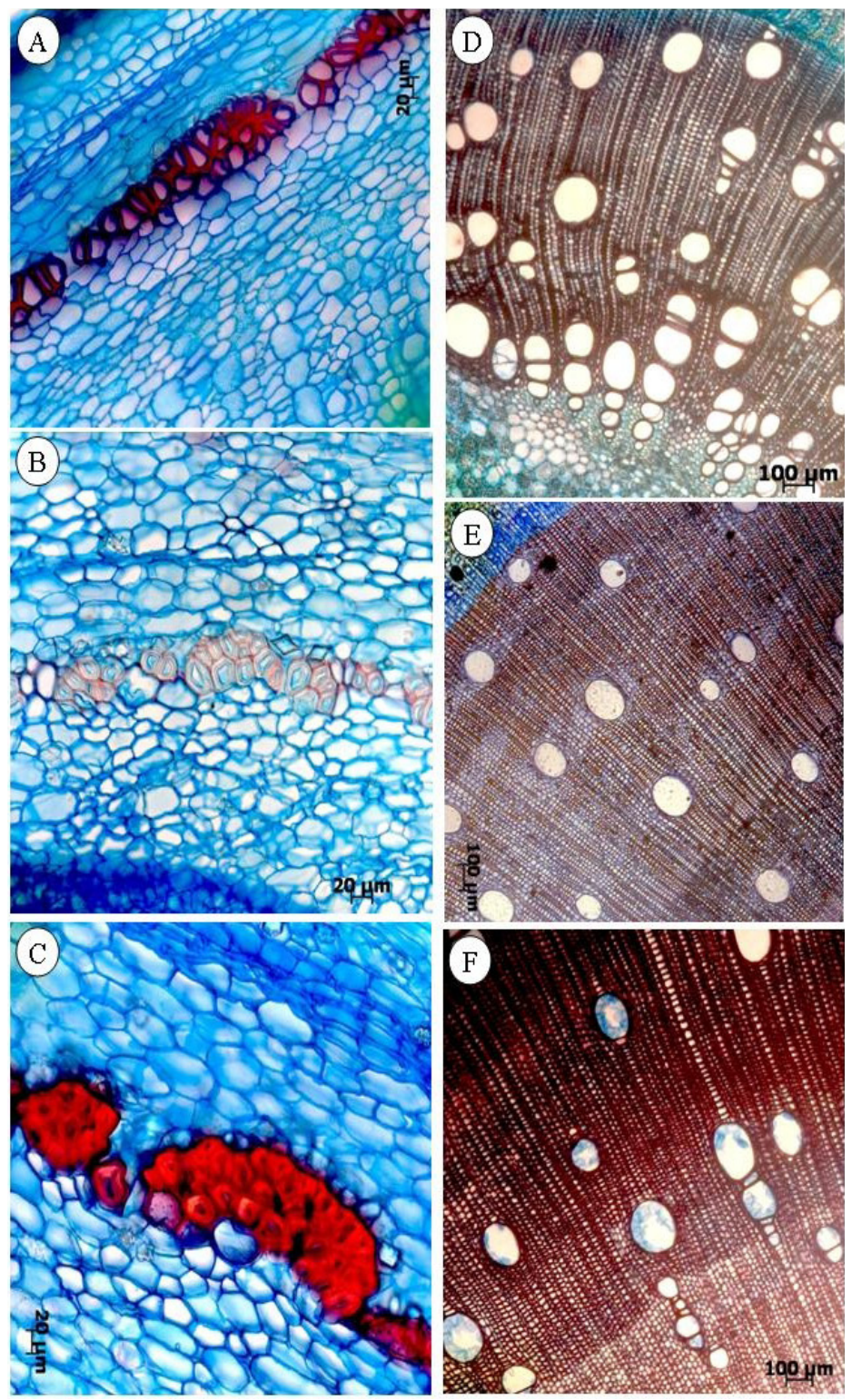

Figures 1. Transverse sections of stem. A. and D. Genotype UnB 99. Close-up of cortical region and pericycle fibers, starch and fibers have large diameters with thin walls, gelatinous fibers are rare. D. Xylem growth ring with little distinct predominance of solitary vessel elements, rare geminates and multiple??? with circular shape, absence of tyloses. B. and E. Genotype UnB 110. B. Close-up of cortical region and pericycle, druse and prismatic/rhomboid crystals and gelatinous fibers in the pericycle. E. Secondary xylem with solitary vessel elements and rare multiple vessels with circular format, the growth ring is poorly differentiated and rare tyloses. C. and F. Manihot graziovii. C. Close-up of cortical region and pericycle, fibers with thick walls and rare gelatinous fibers. F. Secondary xylem with thickened walls and predominance of vessel elements in elliptic format; ring growth was very evident and there are abundant tyloses and regions with large number of layers. 

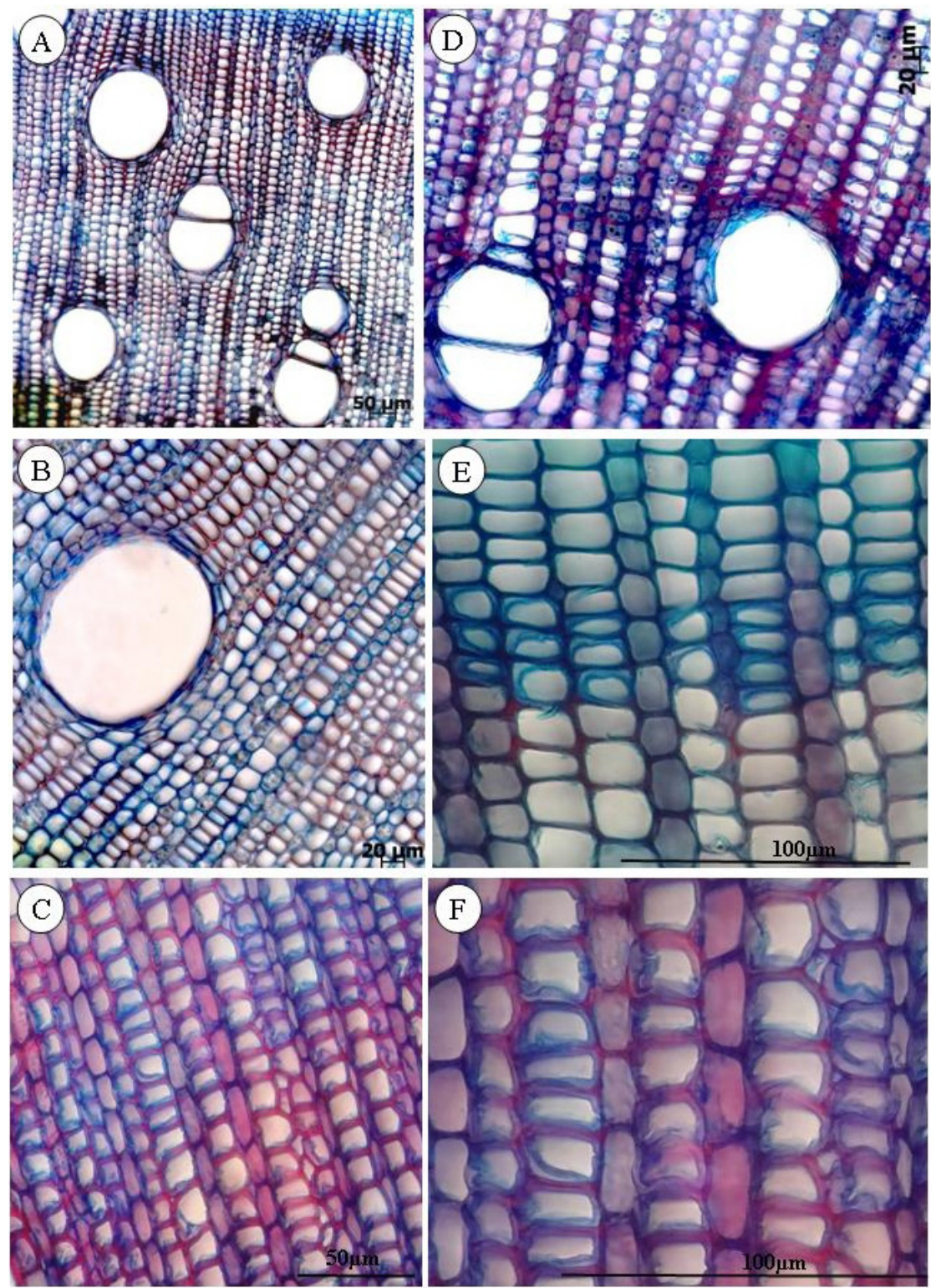

Figure 2. Transversal cross-sections of stem, close-up of secondary xylem. A. and D. Genotype UnB 99. A. Note predominance of solitary vessel elements and fibers, vessel elements are circular, fibers and rays have thin walls. D. There is abundant starch in fibers and rays, there are some gelatinous fibers. B. and E. Genotype UnB 110. Vessel element solitary circular, presence of starch in fibers and ray, cells are larger and have thicker walls. E. Presence of the gelatinous layer in gelatinous fibers internally and absence in the other fibers. C. and F. Manihot glaziovii. Observe rays and fibers of larger size with heavily thickened walls, these cells are bigger and there is occurrence of an abundance of gelatinous fibers. F. Close-up of gelatinous fibers showing the inner layer-G and the presence of starch in parenchyma cells (rays). 
Solitary vessel elements (Figure 1D, E and F) are predominant in relation to geminate and multiple ones in UnB 99 and UnB 110 genotypes; in M. glaziovii there are more geminate and multiple ones, up to 12 vessels. Vessel elements are shorter and have circular shape in UnB 99 and UnB 110 genotypes (Figure 1D-E and Figure 2A and B); they are bigger and have elliptical shape in M. glaziovii (Figure 1F). Tyloses are abundant in M. glaziovii (Figure 1F) and rare in the others (Figure 1D and E).

Primary xylem is present in all stems, with more layers in the UnB 110 genotype (1-3) and M. glaziovii (1-9). In the UnB 110 genotype there are tyloses in some of these cells.

The parenchyma tissue that involves proto- and metaxylem has more starch grains in UnB 99 and UnB 110 genotypes (Figure 3A and B).

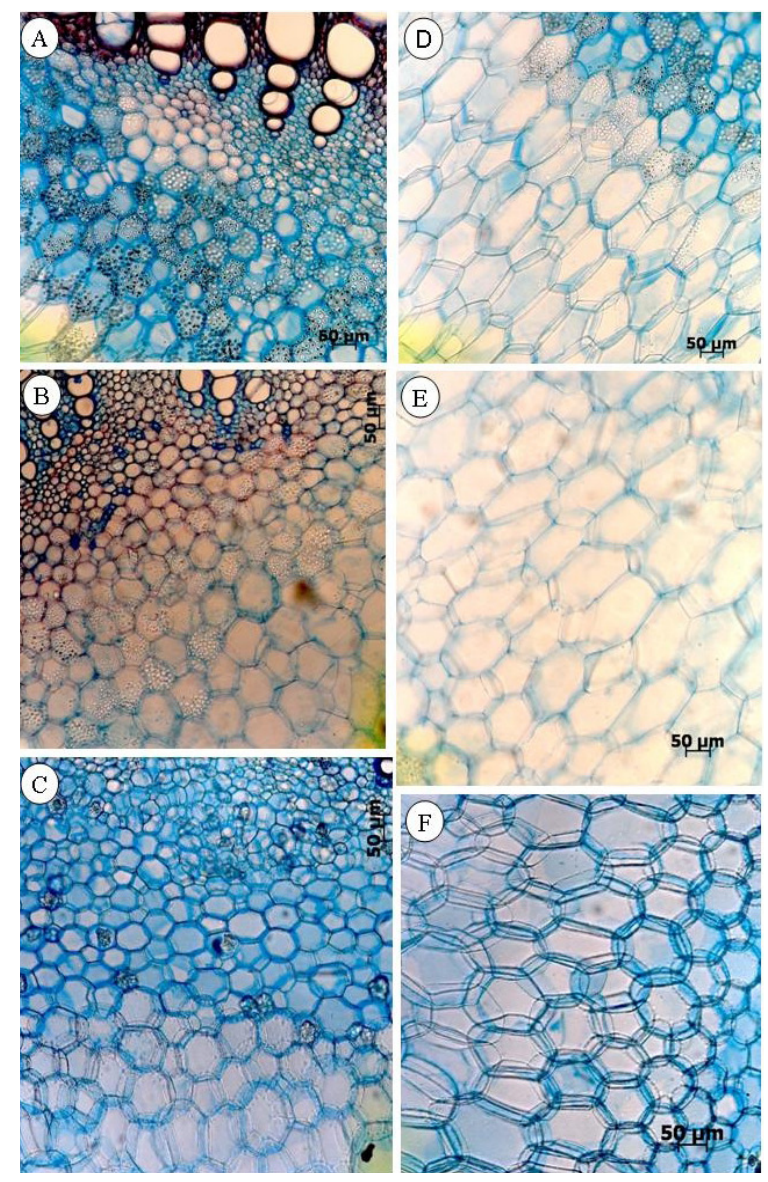

Figures 3. Transverse sections of stem, close-up of primary xylem and medulla. A. and D. Genotype UnB 99. Abundance of starch in parenchyma cells surrounding the primary xylem and isodiametric parenchyma cells of the peripheral medulla. D. Medulla with hexagonal parenchyma cells, they are longer and narrower. B. and E. Genotype 110. B. Presence of starch in parenchyma cells surrounding the primary xylem and isodiametric parenchyma cells of the peripheral medulla. E. Medulla with hexagonal parenchyma cells, these cells are bigger. C. and F. Manihot glaziovii. C. Parenchyma cells of the primary xylem and isodiametric parenchyma cells containing prismatic and druse crystals. F. Medulla with isodiametric and polygonal parenchyma cells, there is no starch inside. 
The peripheral medulla in M. glaziovii has more layers (4-10). Starch grains are found with a higher frequency in the UnB 99 genotype (Figure 3A). They are absent in M. glaziovii, and in the UnB 110 genotype (Figure 3B) with irregular frequency, sometimes in greater amounts, and sometimes with almost no content. However, in M. glaziovii this region has abundant druse and prismatic-rhomboid crystals (Figure 3C).

The non-peripheral medulla has elongated/flattened cells, with hexagonal outline in UnB 99 and UnB 110 genotypes, with cell content of starch grains (Figure 3D and E); while in M. glaziovii these cells have a polyedric outline with few druses (Figure 3F).

\section{DISCUSSION}

In the wild species examined, three aspects of $M$. glaziovii draw attention. First is the predominance of fibers in secondary xylem, which normally have thick walls due to deposition of lignin. Joseleau et al. (2004), studying the secondary cell walls of plants, found that lignin displays physiological functions related to water conductivity and mechanical properties. Deposition of lignin within the cellulose microfibril network of the cell walls imparts hydrophobicity to the conducting cells and brings the necessary mechanical properties to the fibers of supporting tissues in phloem and xylem. There were variations in the thickness of the walls of fibers, from thick lignified in M. glaziovii, moderately lignified in the UnB 99 genotype and thin in the UnB 110 genotype.

The second noted aspect is the presence of gelatinous fibers in the region of the pericycle and secondary xylem. Gales and Toma (2007) studied 19 species of Euphorbia and their findings confirm this idea. They found septate fibers with a thick, moderately and partially gelified lignified secondary wall in the thickness of the secondary xylem. They are predominant at the basis of the aerial stem. In the Euphorbiaceae family, this is the first time the occurrence of gelatinous fibers in the pericycle has been described.

Gelatinous fibers are usually related to the formation of reaction wood, which is the development of fibers in their differentiating xylem by an additional layer at the inner face of the secondary wall in response to gravitational stimuli whose function is to sustain mechanical strength (Dadswell and Wardrop, 1955; Wardrop and Dadswell, 1955; Evert, 2006). As the materials studied do not form reaction wood, it is believed that these fibers are involved in water retention, making them more resistant to drought.

The number of gelatinous fibers is variable between regions and between the materials. In the pericycle, they are abundant in the UnB 110 genotype and lowest in the UNB 99 genotype and are rare in M. glaziovii; in the secondary xylem, the highest number of gelatinous fibers was observed in M. glaziovii, fewer in the UNB 110 genotype and rarely in the UnB 99 genotype. Apparently, more gelatinous fibers increased resistance to drought.

Some authors (Lange et al., 1995; Jiang et al., 2008; Jyske et al., 2010) associate this increase in lignifications with a reaction to water. They usually have a different chemical composition than those synthesized during normal secondary growth development.

It seems that the gelatinous fibers present in the materials under study are an example of response caused by water stress; the G-layer, named due to its gelatinous appearance, is formed in an inner layer in the gelatinous fibers. Norberg and Meier (1966), showed that the composition of the G-layer was constituted primarily of cellulose and was totally free of lignin deposition, which was confirmed by Wada et al. (1995) and Donaldson (2001). 
Chernova and Gorshkova (2007) divided the fibers into two types according to their structure and cell wall composition. The gelatinous fibers were included in type of fibers that have axial orientation of cellulose microfibrils in a well-developed inner layer of the secondary wall. Xu et al. (2006) added that the fibers of this group do not usually contain lignin, a fact confirmed by the tests used in the genotypes and wild species studied, where the G-layer stains in shades of blue showing its cellulosic nature.

The third topic, which we noticed and called attention to, was the presence of starch and prismatic/rhomboid crystals. Starch occurs in the cortical region, the rays of the primary and secondary phloem, the fiber and parenchyma cells in the secondary xylem and medulla. The crystals occur mainly in the cortical region and medulla. The amount of these substances was variable (Graciano-Ribeiro, 2008; Nassar et al., 2008b) in their comparative anatomical study in cassava diploid and tetraploid hybrids. In the referred study, they noticed that the tetraploid type had more starch, prismatic and druse crystals in the cortical parenchyma, larger cells in a portion of the medulla, absence of growth ring, and larger vascular tissues. The distribution of different tissues in the two types conferred more resistance to drought in the tetraploid type than in the diploid one.

In the UnB 110 genotype, which is the result of crossing M. glaziovii x M. esculenta, some characters are found that are probably derived from $M$. esculenta, species with low resistance to drought: abundant starch in the cortical region, in the primary phloem, in the rays of secondary phloem and secondary xylem and in the medulla. Larger cells with hexagonal shape in the medulla, absence of growth rings, well-developed vascular system, and predominance of solitary vessel elements were found. And the characters gelatinous fibers and thickened cell walls from M. glaziovii, species resistant to drought and with brown stem. The larger amount of fiber, starch and crystals and the presence of gelatinous fibers are probably related to the greater drought resistance of M. glaziovii and the UnB 110 genotype. This set of anatomical characters present in the hybrid 110 makes it more resistant to drought and a good genotype for adoption in dry areas. Okogbenin et al. (2003) found that response to drought stress was significantly influenced by genotype.

What attracts attention is a certain morphological character present in M. glaziovii in clone 110 and in clones adapted to the Brazilian Northeast: the dark brown of the stem and root bark. It seems that this character is associated with tolerance to drought and can be used as a morphological marker used for selection of clones tolerant to drought.

Another noticeable aspect is the presence of growth rings in secondary xylem and tyloses in the vessel elements that require more meticulous analysis in the future.

Wild species and their progeny have a dark brown color. This is noted in all clones adapted to semi-arid Northeastern Brazil, while clone UnB 99, which came from humid southern Brazil, has a white stem. This is noticeable in all indigenous clones adapted to the south of this country and to humid tropical Amazon. This leads us to believe that there is some kind of association and possibly close linkage between stem color and this specific anatomical structure.

\section{ACKNOWLEDGMENTS}

This study has been carried out with the help of the Brazilian National Research Council (CNPq). The above mentioned living collection was established with help from the Canadian International Development Research Centre. 


\section{REFERENCES}

Chernova TE and Gorshkova TA (2007). Biogenesis of plant fibers. Russ. J. Dev. Biol. 38: 221-232.

Dadswell HE and Wardrop AB (1995). The structure and properties of tension wood. Holzforschung 9: 97-104.

De Tafur SM, El-Sharkawy MA and Cadavid LF (1997). Response of cassava (Manihot esculenta Crantz) to water stress and fertilization. Photosynthetica 34: 233-239.

Donaldson LA (2001). Lignification and lignin topochemistry - an ultrastructural view. Phytochemistry 57: 859-873.

El-Sharkawy MA (2004). Cassava biology and physiology. Plant Mol. Biol. 56: 481-501.

Evert RF (2006). Esau's Plant Anatomy. John Wiley and Sons Inc., New Jersey.

Gales RC and Toma C (2007). Comparative anatomy of the vegetative organs of some Euphorbia species (Euphorbiaceae Juss.) from the Romanian flora. Rom. J. Biol. Plant Biol. 51-52: 39-47.

Graciano-Ribeiro D (2008). Anatomy of polyploid Cassava and its interspecific hybrids. Gene Conserv. 7: 620-635.

Graciano-Ribeiro D, Hashimoto DY, Nogueira LC, Teodoro D, et al. (2009a). Internal phloem in an interspecific hybrid of cassava, an indicator of breeding value for drought resistance. Genet. Mol. Res. 8: 1139-1146.

Graciano-Ribeiro D, Hashimoto DYC, Nogueira LC and Nassar NMA (2009b). Vascular bundles in Manihot esculenta Crantz (Euphorbiaceae). Gene Conserv. 8: 808-817.

Jiang S, Xu K, Wang YZ, Ren YP, et al. (2008). Role of GA3, GA4 and uniconazole-P in controlling gravitropism and tension wood formation in Fraxinus mandshurica Rupr. var. japonica Maxim. seedlings. J. Integr. Plant Biol. 50: 19-28.

Johansen DA (1940). Plant Microtechnique. McGraw Hill, New York.

Joseleau JP, Imai T, Kuroda K and Ruel K (2004). Detection in situ and characterization of lignin in the G-layer of tension wood fibres of Populus deltoides. Planta 219: 338-345.

Jyske T, Holtta T, Makinen H, Nojd P, et al. (2010). The effect of artificially induced drought on radial increment and wood properties of Norway spruce. Tree Physiol. 30: 103-115.

Kraus JE and Arduin M (1997). Manual Básico de Métodos em Morfologia Vegetal. Seropedica, Rio de Janeiro.

Lange BM, Lapierre C and Sandermann H Jr (1995). Elicitor-induced spruce stress lignin (structural similarity to early developmental lignins). Plant Phisiol. 108: 1277-1287.

Levitt J (1972). Responses of Plants to Environmental Stresses. Academic Press, New York, London.

Luque R, Sousa HC and Kraus JE (1996). Métodos de coloração de Roeser (1972) - modificado - e Kropp (1972) visando a substituição do azul de astra por azul de alcião 8GS ou 8GX. Acta Bot. Bras. 10: 199-211.

Nassar NM (2002). Cassava, Manihot esculenta Crantz, genetic resources: origin of the crop, its evolution and relationships with wild relatives. Genet. Mol. Res. 1: 298-305.

Nassar NMA (2007). Wild cassava, Manihot spp. to improve the crop. Geneconserve 6: 387-414.

Nassar NM, Hashimoto DY and Fernandes SD (2008a). Wild Manihot species: botanical aspects, geographic distribution and economic value. Genet. Mol. Res. 7: 16-28.

Nassar NM, Graciano-Ribeiro D, Fernandes SD and Araújo PC (2008b). Anatomical alterations due to polyploidy in cassava, Manihot esculenta Crantz. Genet. Mol. Res. 7: 276-283.

Norberg PH and Meier H (1966). Physical and chemical properties of the gelatinous layer in tension wood fibres of aspen (Populus tremula L.). Holzforschung 20: 174-178.

Okogbenin E, Ekanayake IJ and Porto MCM (2003). Genotypic variability in adaptation responses of selected clones of Cassava to drought stress in the Sudan Savanna zone of Nigeria. J. Agron. Crop Sci. 189: 376-389.

Paiva JGA, Fank-de-Carvalho SM, Magalhães MP and Graciano-Ribeiro D (2006). Verniz vitral incolor 500 ${ }^{\circledR}$ : uma alternativa de meio de montagem economicamente viável. Acta Bot. Bras. 20: 257-264.

Taiz L and Zeiger E (1998). Plant Physiology. The Benjamin/Cummings Publishing Company Inc., Redwood City.

Wada M, Okano T, Sugiyama J and Horii F (1995). Characterization of tension and normally lignified wood cellulose in Populus maximowiczii. Cellulose 2: 223-233.

Wardrop AB and Dadswell HE (1955). The nature of reaction wood. IV. Variations in cell wall organization of tension wood fibres. Austr. J. Bot. 3: 177-189.

Xu F, Sun RC, Lu Q and Jones GL (2006). Comparative study of anatomy and lignin distribution in normal and tension wood of Salix gordejecii. Wood Sci. Technol. 40: 358-370. 